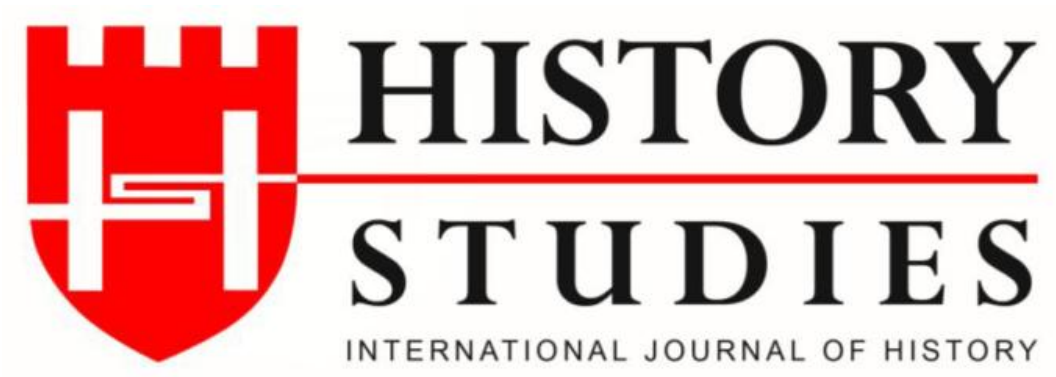

ISSN: 13094173 (Online) 1309 - 4688 (Print)

Volume 12 Issue 5, October 2020

DOI Number: 10.9737/hist.2020.926

Araştırma Makalesi

Makalenin Geliş Tarihi: 03.08.2020 Kabul Tarihi: 15.09.2020

Atıf Künyesi: Fatma Çapan, "Fatımîlerin Doğu Politikası ve Doğu Roma İmparatorluğu İle İlişkileri”, History Studies, 12/5, Ekim 2020, s. 2413-2425.

\title{
Fatımîlerin Doğu Politikası ve Doğu Roma İmparatorluğu İle İlişkileri
}

Eastern Policy of The Fatimi and Relations With The The Eastern Roman Empire

\author{
Dr. Fatma Çapan \\ ORCID No: 0000-0002-8682-4179 \\ Gaziantep Üniversitesi
}

$\ddot{O} z$

Fatımîler Batı Akdeniz'de hakimiyeti tesis etmek amaciyla Sicilya ve Güney İtalya'da Doğu Roma İmparatorluğu ile mücadele ederken doğuda Mısır gibi stratejik önemi yüksek bölgelere güçlü bir harekât gerçekleştirememişlerdir. Ancak islam dünyasında güçlü ve tek hükümdar olabilmenin en önemli gerekliliklerinden biri Misır gibi bir orta merkeze sahip olmaktı. Hindistan-Avrupa ticaret yolunun üzerinde ve üç kıtanın birleştiği noktada bulunan, Kızıldeniz ve Akdeniz'e kıyısı olan önemli limanlara sahip olan, Asya ve Afrika arasında kara kervan yollarının rotasında bulunan Mısır'ın konumu ise bu noktada Fatımîler için ayrı bir önem arz etmiştir. 912'den 969 yılına kadar yapılan dört askeri hareket sonucunda Halife Muiz Lidînillah(953-972) döneminde Mısır'ın fethi gerçekleştirilmiştir. Fatımîler Mısır'ın fethinden sonra Suriye ve Hicaz bölgesinde de hakimiyetlerini tesis etmek için bir takım müdahalelerde bulunmuştur. Ancak Fatımîlerin Mısır, Suriye ve Hicaz bölgesinde hakimiyet kurması Doğu Roma İmparatorluğu'nun Doğu Akdeniz'deki varlığını tehdit etmeye başlamıştır. Dolayısıyla Fatımîler ve Doğu Roma İmparatorluğu Akdeniz'de hakim olabilmek için birbirleri ile mücadele etmişlerdir. Bu mücadeleler Selçukluların güçlü bir siyasi teşekkül olarak ortaya çıkması ve Haçlı seferlerinin başlamasına kadar devam etmiştir.

Anahtar Kelimeler: Fatımîler, Doğu Roma İmparatorluğu, Mısır, Suriye, Hicaz.

\begin{abstract}
While Fatimids were struggling with the Eastern Roman Empire in Sicily and Southern Italy in order to establish domination in the Western Mediterranean, they could not perform a strong operation in regions with high strategic importance such as Egypt in the east. However, one of the most important requirements to be a strong and sole ruler in the Islamic world was to have a central center like Egypt. The location of Egypt, which is located on the India-Europe trade route and at the junction of the three continents, has important harbors along the Red Sea and the Mediterranean, and on the route of the black caravan routes between Asia and Africa, was of special importance for the Fatimids at this point. The conquest of Egypt was carried out in the period of Caliph Muiz Lidînillah (953-972) as a
\end{abstract}


Fatımîlerin Doğu Politikası ve Doğu Roma İmparatorluğu İle İlişkileri

result of four military movements from 912 to 969 . After the conquest of Egypt, Fatimîds made some interventions to establish their domination in Syria and Hejaz region. However, the domination of Fatimids in Egypt, Syria and Hejaz started to threaten the existence of Eastern Rome in the Eastern Mediterranean. Therefore, both Fatimids and the Eastern Roman Empire battled with each other to dominate the Mediterranean. These struggles continued until the emergence of the Seljuks as a strong political organization and the start of the Crusades.

Keywords: Fatimids, Eastern Roman Empire, Egypt, Syria, Hejaz.

\section{Giriş}

Fatımî Devleti kuruluş felsefesi itibariyle hilafetin Hz. Muhammed ve onun kızı Fatıma'nın soyundan gelenlere ait olduğu inancıyla halifelik davası ile ortaya çıkmıştır. $\mathrm{Bu}$ amaç doğrultusunda Hz. Ali'nin Şia's ${ }^{1}$ yani taraftarı olanlar özellikle Emeviler döneminden başlayarak muhalif hareketlere başlamışlardır. Ancak Emeviler, Muaviye döneminden itibaren Hz. Ali taraftarlarına karşı oldukça baskıcı bir politika izlemişlerdir. Buna rağmen Şiîler de Emevilere karşı isyankâr hareketlerinden vazgeçmemiş̧lerdir. Nitekim Kureyş kabilesi arasında Haşimi-Ümeyye çatışmasının bir sonucu olarak Emevilere karşı çıkan Abbasi ihtilâlini de fırsat bilen Şiîler bu harekete destek vermekten de çekinmemişlerdir. Ancak Şiîler, Abbasiler döneminde de bekledikleri makam ve mevkilere getirilmemiş hatta önemsenmemişlerdir. Bu nedenle muhalif hareketlerini daha da güçlendirmişler ve Şiî hareketin savunuculuğu ve yayılmasında görevlendirdikleri Daî’ler aracılığıyla gittikleri yerlerde açı veya gizli olarak propagandalarını yapmaya devam etmişlerdir. Nitekim bu hareketlerin sonucu olarak Ubeydullah El-Mehdi(910-934) Tunus'a giderek hakimiyetini tesis etmiş ve Fatımî Devleti'ni kurmuştur. Fatımî Devleti'nin kurulduğu andan itibaren ilk ve en önemli hedefi ise İslam dünyasının en güçlü ve hatta tek hükümdarı olabilmektir. Bu noktada Fatımîlerin en önde gelen düşmanları ise Sunni Abbasi Devleti ve o günkü diğer Sunni Müslüman hükümdarlar olan Selçuklu hükümdarları ve Endülüs Emevi hükümdarları olmuștur.

Fatımîlerin İslam dünyasında en güçlü ve tek hükümdar olabilme hedefleri yolunda başlangıçta karşılarına bazı zorluklar çıkmıştır. Bunlardan biri kuruldukları yer olan Tunus'un stratejik konumu itibariyle güvenliklerini sağlamak amaciyla öncelikle Batı Akdeniz'de hakimiyeti tesis etmeleri ihtiyacıdır. Nitekim bu noktada özellikle Sicilya ve Güney İtalya'da Doğu Roma İmparatorluğu ile mücadele etmek zorunda kalan Fatımî Devleti oldukça büyük mücadeleler vermek zorunda kalmıştır. Özellikle Sicilya Adası'nda iç isyanlar, muhalif hareketler, gönderilen valilerin bunları bastırmakta kabiliyetsizlikleri nedeniyle büyük sorunlar yaşanmıştır. Ancak Sicilya'nın idaresinin Kelbî ailesine verilmesinden sonra Fatımî hakimiyeti tesis edilmiş ve burada önemli sorunlar yaşanmamaya başlamıştır. Doğu Roma İmparatorluğu ise her firsatta hem Sicilya'da hem de Güney İtalya'da Fatımîler aleyhine gelişen durumları firsata çevirmeyi bilmiştir. Bazen iç isyanlara açık veya gizli destek verirken bazen de ordular göndererek Fatımîler ile hem karada hem de denizde mücadele etmiştir. Diğer yandan Batı Akdeniz'de en önemli Fatımî düşmanlarından olan Endülüs Emevi Devleti de Doğu Roma İmparatorluğu ile işbirliği yapmaktan çekinmemiştir. Tüm bunlara rağmen Fatımî Devleti A ğlebilerden devraldığı ve daha da güçlendirdiği donanma sayesinde Batı Akdeniz siyasetinde güçlü konuma gelmeyi başarmıştır².

\footnotetext{
${ }^{1}$ Fatma Çapan, "Batı Akdeniz'de Doğu Roma İmparatorluğu-Fatımî Siyasi İlişkileri” Kahramanmaraş Sütçü İmam Üniversitesi Sosyal Bilimler Dergisi, C.17, S.11, Kahramanmaraş 2020, s.275.

${ }^{2}$ Çapan, agm, s.288-289.
} 
Fatımîler Batı Akdeniz'de mücadele ederken devletin kuruluş felsefesinin tersine hareket edildiği ve Abbasilere karşı gereken hareketin yapılmadığını düşünen bazı Şiî daileri Halife Ubeydullah El-Mehdi'den ayrılarak Karmatî $\hat{~}^{3}$ harekete katılmıştır. ${ }^{4}$ Esasen Halife Ubeydullah El-Mehdi'nin de hedefi Abbasilere karşı mücadele etmek ve İslam dünyasının hakimiyetini ele geçirmektir ancak Tunus'a gittikten sonra tesis ettiği yeni hilafetin amaçlarını gerçekleştirme yolunda bazı zorluklarla karşılaşmıştır. Nitekim bahsedildiği üzere dışarıda devletin güvenliğini sağlamak amacıyla Batı Akdeniz'de yapılan mücadeleler dolayısıyla siyasi, askeri ve ekonomik sıkıntılar, içeride ise Malikî alimlerinin halifenin fikirlerine ve hilafetine karşı olması bunda etkin rol oynamıştır. Diğer yandan Kuzey Afrika'nın doğal coğrafyasının dağlık olması da hareket kabiliyetini engelleyen önemli faktörlerden olmuştur. ${ }^{5}$

Halife Ubeydullah El-Mehdi'ye karşı Şiî dailerinin bu eleştirilerine rağmen kendi hilafeti döneminde Mısır'a iki kez harekât düzenlemesi İslam dünyasında gerçekleştirmek istediği amaçlarının arkasında durduğunu göstermektedir. Nitekim o, İslam dünyası içerisinde güçlü ve tek hükümdar olmak için Doğu ve özellikle Mısır'ı ele geçirmesi gerektiğini anlamıştır. Çünkü İslam dünyasında liderliği ele geçirmek için bir orta merkeze ihtiyaç duymuştur. HindistanAvrupa ticaret yolunun üzerinde ve üç kıtanın birleştiği noktada bulunan, Kızıldeniz ve Akdeniz'e kıyısı olan önemli limanlara sahip olan, Asya ve Afrika arasında kara kervan yollarının rotasında bulunan Mısır'ın konumu ise bu noktada Halife için göz ardı edilemez bir ayrintı olmuştur. ${ }^{6}$

Fatımîlerin Mısır'ı ele geçirme çabaları onları Şam ve Hicaz'ın egemenliğini de ele geçirmeye yöneltmiştir. Çünkü Şam ve Hicaz'ı ele geçirmek Fatımîlerin çok önemli bir dinî merkeze sahip olması anlamına da gelmektedir. Zira bu kutsal memleketleri içine alan bölgelere hakim olanlar İslam devletine de fiilen hakim olmuş sayılırlardı. ${ }^{7}$ Aynı zamanda Mısır'ın konumu Fatımîlere ait toprakların birbirlerine bağlanmasını da kolaylaştırırdı. Diğer yandan Fatımîlerin başkenti olan Mehdiyye'nin konumu stratejik açıdan Mısır'ın avantajlarına sahip olmadığı için Mısır'ın ele geçirilmesi önemli bir gereklilikti. ${ }^{8}$ Ayrıca Mısır, tarımsal verimliliği açısından da büyük önem arz eden bir bölge olmasının yanı sıra Fatımîler için Suriye, Hicaz ve Bağdat kapısını aralayan bir konuma sahipti. ${ }^{9}$

\section{Fatımîlerin Mısır’ı Ele Geçirmesi Öncesindeki Gelişmeler}

Fatımîler, 912'den 969 yılına kadar Mısır'a dört askeri hareket düzenlemiştir. ${ }^{10}$ Bunlardan ikisi Halife Ubeydullah El-Mehdi(910-934) döneminde üçüncüsü Halife Kâim-Biemrillâh(934946) döneminde sonuncusu ve başarılı olanı ise Halife Muiz Lidînillah(953-972) döneminde gerçekleştirilmiştir. ${ }^{11}$ Halife Ubeydullah El-Mehdi(910-934) ve oğlu Kâim-Biemrillâh döneminde yapılan Mısır seferleri Abbasilerin Mısır'a kuvvetli destek göndermesi nedeniyle başarısızlığa uğramıştır. Ancak bu seferlerde Fatîmiler her ne kadar yenilgiye uğrasalar da bu

\footnotetext{
${ }^{3}$ Bkz. Riyad El-Cevarî, El-Siyase el-Hariciyye Lil-Devletu'l-Fatimiyye M.968-1035, Kufa Üniversitesi Yayınları, Kufa, 2007, s.86.

${ }^{4}$ Aydın Çelik, Fâtımîler Devleti Tarihi(909-1171), TTK Yayınları, Ankara,2018, s.172.

${ }^{5}$ Ayman Fu'at Seid, El-Devletu'l-Fatimiye Tefsir Cedid, Mekteba El-Usra Yayınları, 2007,s,124.

${ }^{6}$ Seid, age, s,124;Çelik, age, s.206.

${ }^{7}$ Hasan İbrahim, Tarih El-devletu'l-Fatimiyye, Mısır Lİl-tiba'a ve El-Neşir Yayınları, Kahire, 1958,s.113.

8, Abdullah Cemaleddin, Devletu'l-Fatimiye Kiyemuha fi El-Mağrib ve İntikaliha ile Misır, Dar'ul-Sekafe Yayınları, Kahire, 1991,s.94.

${ }^{9}$ Çelik, age,.172.

10 İbrahim, age, ,s.113.

${ }^{11}$ Çelik, age,s.171-172
} 
sayede coğrafyayı tanıma firsatı bulmuşlardır. Diğer yandan Şiî dailerinin Mısır'da yaptıkları propagandalar sayesinde çok sayıda Mısırlının İsmâiliyye mezhebine katılması sağlanmıştır. ${ }^{12}$

953 yılında Fatımî tahtına çıkan Halife Muiz Lidînillah öncelikle Endülüs Emevi Halifesi III. Abdurrahman ile mücadeleye başlamıştır. 954 yılında başlayan savaş sırasında III. Abdurrahman Fatımîlere karşı Doğu Roma İmparatoru VII. Konstantinos ile ittifak yapmış, diğer yandan da Fatımîlerin doğudaki komşusu Mısır'daki İhşîdîleri güçlendirmek için Şiîliğe karşı olan Mâlikilere dağıtılmak üzere yüklü miktarda para göndermiştir. ${ }^{13}$ Ancak III. Abdurrahman bu politikalarında başarıya ulaşamamış ve Halife Muiz Lidînillah neredeyse Endülüs'e girebilecek kadar güçlenmiştir. Nitekim bundan sonraki süreçte Doğu Roma komutanı Nikephoros Phokas'ın 961 yılında Girit Adası'nı işgal etmesi üzerine Endülüs Emevileri ile fiilen savaş bırakılmış ancak düşmanlık devam etmiştir. ${ }^{14}$

Fatımî Halifesi Mansûr Billah(946-953) döneminde Doğu Roma İmparatorluğu ile Fatımîler arasında bir barış anlaşması yapılmıştır. ${ }^{15}$ Ancak Mansûr Billah'dan sonra yerine geçen oğlu Muiz Lidînillah döneminde ilişkiler yeniden bozulmuştur. 956-957 tarihlerinde yapılan savaşlarda Doğu Roma orduları yenilgiye uğratılmıștır. ${ }^{16}$ Bunun üzerine 958 yılında Doğu Roma İmparatorluğu gönderdiği elçiler aracıllı̆ıyla Muiz-Lidînillah'tan ateşkes istemiştir. Fatımîler bu sırada Mısır'a yönelmek niyetinde olduğundan bu ateşkes teklifini beş yıllığına kabul etmiştir. ${ }^{17}$

Doğu Roma İmparatorluğu Fatımîlerle yaptı̆ğ bu ateşkes anlaşması sırasında Fatımîlerin Endülüs Emevileri ile savaş halinde olmasını firsat bilerek, 960 yılında Ihşidîlere bağlı Girit'e büyük bir sefer düzenlemiştir. Çünkü Girit'in Müslümanların elinde olması Doğu Roma için büyük bir tehdit oluşturmuştur. Girit'e hakim olmak hem Doğu Roma kıyılarının güvenliği açısından hem de Ege'de ve Anadolu' da birçok imkana sahip olmak açısından önem taşıyordu. ${ }^{18}$ Doğu Roma'nın Girit saldırıları sırasında Abbasilere bağlı olan adanın sunni Müslüman halkı zorda kalarak hem Fatımîlerden hem de Ihşidîlerden yardım istemiştir. Bunun üzerine Fatımî Halifesi, Doğu Roma İmparatoruna bir mektup göndererek Girit ahalisine karşı düşmanca tutumun sona erdirilmesini aksi takdirde aralarındaki anlaşmanın feshedileceğini duyurmuştur. Ayrıca Girit halkının şimdi Abbasilere sadık olmadığını kendilerinden yardım talep ettiğini, bu nedenle de kendilerinden yardım isteyen bu insanlara savaş açmakta ısrar edilirse Doğu Roma'ya karşı savaş açacağını bildirmiştir. ${ }^{19}$ Ancak Mısır'da Abbasilere bağlı olan sünni İhşîdilerin siyasi nedenlerle Fatımîlerin işbirliği teklifine yanaşmaması nedeniyle Girit'e gereken yardım sağlanamamıştır. İmparator II.Romanos(959-963) döneminde yapılan bu sefer sonucunda Girit 150 yıl sonra 961 yılında yeniden Doğu Roma'nın eline geçmiştir. Diğer yandan bu noktada Endülüs Emevi Devleti ile Fatımîler arasındaki üstünlük çekişmesi de Doğu Roma'nın işini kolaylaştıran en önemli etkenlerden biri olmuştur. ${ }^{20}$

\footnotetext{
${ }^{12}$ Çelik, age, s.85-87.

${ }^{13}$ Celik, age, s.154-155.

${ }^{14}$ Çelik, age,s.155-159.

15 Ömer Tokuş "Fâtımîler ile Sicilya ve Güney İtalya Arasındaki Münasebetler", Tarih Dergisi, S.59,İstanbul 2014 s.38; Murat Öztürk, Fâtımiler'in Deniz Gücü ve Akdeniz Hâkimiyeti, İstanbul Üniversitesi Sosyal Bilimler Enstitüsü (Yayınlanmamış Doktora Tezi), İstanbul 2012, s. 82-83.

16 Öztürk, agt,s. 85-87.

${ }^{17}$ Ahmad Tevfik Madenî, El-Muslimin fi Cezire Siklliyye ve Cenup İtalya, Mektaba İstikame Yayınları., Tunus, 1981, s.151.

${ }^{18}$ Metrofan Vasiliyeviç Levtchenko, Bizans, Çev: Erdoğan Berktay, Milliyet Yayınları, İstanbul 1979 s.233;Öztürk, agt, s.91-92.

19 Öztürk, agt, s.94-95.

${ }^{20}$ Nihat Yazılıtaş, Fâtımî Devleti'nde Türkler, TTK Yayınları, Ankara 2009, s.48;Öztürk, agt,s.96-97;Çapan, agm, s.288.
} 
Girit' in Doğu Roma'nın eline geçmesiyle birlikte Müslüman akınları da büyük bir darbe almış ve Doğu Akdeniz'de Müslüman ticaret gemilerinin dolaşımına önemli bir darbe vurulmuştur. ${ }^{21}$ Doğu Roma İmparatorluğu'nun Girit'e saldırması üzerine Fatımîlerle yapılan ateşkes anlaşması da ortadan kalkmıştır. Doğu Roma'nın Girit'te yaptıklarının intikamını almak isteyen Fatımî Halifesi Muiz-Lidînillah 961 yılının sonlarına doğru Sicilya'nın kuzeydoğusunda Fatımîlere karşı muhalif durumundaki Hıristiyanların üsleri konumunda olan Ramte bölgesine saldırmaya karar vermiştir. Bu nedenle Sicilya valisi Ahmed b. Hasan El-Kelbî’ye hareket için izin vermiştir. Ramte'de bulunan Rumlar da bunun üzerine İstanbul'dan yardım istemiştir. Ancak o sırada Doğu Roma tahtında oturan İmparator II. Romanos ölmüş arkasında dul eşi Theophano ve iki küçük oğlunu bırakmıştı. Theophano yönetimde başarılı bir tutum sergileyemediği için asker imparator Nikephoros Phokas ile evlenerek onu tahta çıkarmıştır. ${ }^{22}$ İmparator Sicilya Adası'ndaki duruma kayıtsız kalmayarak 40.000 kişilik bir ordu göndermiştir. Tarihte Hufre(Hendek) Savaşı olarak bilinen savaşta Doğu Roma ordusu büyük yenilgiye uğramış ve çok sayıda esir vermiştir. ${ }^{23}$ Böylece Batı Akdeniz'de Fatımî hakimiyeti daha da güçlenmiştir. Doğu Roma her zaman olduğu gibi yine Fatımîler ile barış yapmak zorunda kalmıştır. Fatımî Halifesi Muiz-Lidînillah ise o sırada Mısır seferine hazırlandığı için Doğu Roma ile anlaşmayı uygun görmüştür. ${ }^{24}$

\section{Fatımîlerin Mısır'ı Ele Geçirmesi}

Volume 12

Issue 5

October

2020

Halife Muiz Lidînillah Doğu Roma İmparatorluğu'na karş1 elde ettiği başarılar sonucunda devletin kuruluş felsefesine uygun bir şekilde Misır'a doğru yönelmeye karar vermiştir. Esasen Şiî daileri tarafından Mısır'a yönelme konusunda sürekli sıkıştırılan Halife Muiz Lidînillah bu konuda uygun zamanın geldiğine inanmıştır. Daha önce Şiî dailerine vaktin henüz gelmediğini söyleyen Halife, gücünün zirvesine ulaştığı anda artık İslam dünyasında tek hükümdar olabilmek için bu hedefine kendisini en yakın konuma getirecek Mısır'a sefer düzenlemeye karar vermiştir. Nitekim İslam dünyasında da şartlar halifenin lehine dönmüştür. Abbasi Devleti iyice güç kaybetmiş 945 yılında idare Şiî Büveyhoğullarının eline geçmiş, Abbasi otoritesi ve nüfuzu hakim olduğu bölgelerde zayıflamıştır. ${ }^{25}$

Fatımîlerin ele geçirmek istediği Mısır'da da şartlar Fatımîlerin lehine oluşmaya başlamıştır. Nitekim askerlik ve siyasette zekası ile bilinen İhşîlî hükümdarı Kafûr'un ölmesiyle birlikte Fatımîlerin amacının gerçekleşmesi yolunda önemli bir engel ortadan kalkmıştır. Zira onun ölümünden sonra yerine çocuk yaşta olan oğlu Ahmed geçmiş, Vezir Abu'l-Fazil b. Furat ise Misır ordusunun isteklerini yerine getirmeye muvaffak olamamıştır. Diğer yandan Nil Nehri'nin suyunun eksilmeye devam etmesi nedeniyle hayat pahalılığ başlamıştır. Bunun üzerine bu durumdan rahatsız olan bazı ayanlar Fatımî Halifesine mektup yazarak Mısır'ı teslim etmek için onu davet etmişler ve ordusunu göndermesini istemişlerdir. ${ }^{26}$ Bu gelişmeler üzerine Mısır, Fatımî kumandanı Cevher Es-Sıkıllî tarafından 969 yılının Temmuz ayında ele geçirilmiş ve böylece Mısır'da İhşî̀î hakimiyeti sona ererek Fatımîlerin Mısır dönemi başlamıştır. ${ }^{27}$ Aynı zamanda

\footnotetext{
${ }^{21}$ Öztürk, agt,s.98.

${ }^{22}$ Levtchenko, age, s.233.

23 Öztürk, agt,s.99-101.

${ }^{24}$ Tokuş, agm,s.41; Yazılıtaş, age, s.48-49.

${ }^{25}$ Çelik, age, s.172-173.

${ }^{26}$ Seid, age, s,133; Çelik, age, s.176-177.

${ }^{27}$ Bernard Lewis, Uygarlık Tarihinde Araplar, Pegasus Yayınları., İstanbul, 2006, s.160-161;İbnü’l Esir, El Kâmil

Fi’t Tarih, C.VIII., Çev:Ahmet Ağırakça, Bahar Yayınları, İstanbul 1986, s.507;Yazılıtaş, age, s.50-51.
} 
komutan Cevher Es-S1kıllî, o sırada Tunus'ta bulunan Fatımî Halifesi Muiz-Lidînillah'a haber göndererek onu Mısır'a davet etmiştir. ${ }^{28}$

Rivayet edilene göre Fatımî Halifesi Muiz Lidînillah bu sefer için yirmidört milyon altın dinar harcamıștır. Nitekim o bu büyük serveti Mısır'ı ele geçirmek ve ardından Şam ve Hicaz’1 ele geçirerek Abbasi Halifeliğini ortadan kaldırmak ve İslam dünyasının tek siyasi ve dini lideri olmak için harcamıştır. ${ }^{29}$ Bazı tarihi kaynakların değerlendirdiğine göre Mısır'a gelen Fatımî ordusunun sayısı yaklaşık 100.000 kişidir. El-Mıkrizî bu konu ile ilgili 'Mısır'ın bütün ayanları gelen Fatımî ordusunu karşıladılar, onlar sanki Arafat topluluğu gibiydiler. Hatta İskender'in ordusundan sonra Fatımî Halifesi El-Muiz'in ordusu kadar büyük bir ordu Mısır'a gelmemiş, İhşidîler'in ordusu parçalar halinde olduğu için Fatımî ordusu karşısında neredeyse hiç mukavemet gösterememiştir" demiştir. ${ }^{30}$

Fatımîler Mısır'ın ele geçirilmesinden sonra bir yıl geçmeden Suriye üzerine yöneldiler. Bu sırada Suriye, İhşîdî hakimiyetinde bulunuyordu. Bu nedenle zaten Mısır topraklarına ait olan Suriye'nin bu konumunu korumak gerekiyordu. Diğer yandan Suriye, Misır'a kuzeyden yani Abbasiler ve Doğu Roma İmparatorluğu'ndan gelebilecek tehlikelere karş1 adeta bir güvenlik kalkanı konumunda olan bir yerdi. Ayrıca Karmatîlerin Suriye'yi ele geçirme ihtimali de bunu zorunlu kılıyordu. ${ }^{31} \mathrm{Bu}$ nedenlerle Mısır Fatihi Cevher El-Sıkılî 970 yılında bir ordu hazırlamış ve başına komutan Cafer b. Felah El-Kitamî getirerek yola çıkarmıştır. 970 yılı Eylül ayında Cafer Şam'ı(Dımaşk) ele geçirmeyi başarmıştır. ${ }^{32}$ Daha sonra Beyrut, Sayde ve Tarablus da alınmış ve böylece Antakya dışında bütün Suriye memleketleri Fatımîlerin egemenliği altına girmiştir. Bu toprakların idaresine de Emir Seyf el-devle Munzir getirilmiştir. ${ }^{33}$ Komutan Cefar b. Felah gerçekleştirdiği bu zaferden sonra 970 yılının Aralık ayında kölesi Fütuh kumandasındaki 20.000 kişilik ordusunu Antakya, Taberiyye ve İskenderun'a Doğu Romalılarla savaşmak üzere göndermiştir. Ancak bu ordu yenilgiye uğrayarak Dımaşk'a geri çekilmek zorunda kalmıştır. ${ }^{34}$

Mısır ve Suriye'yi egemenliği altına alan Fatımîlerin bundan sonraki en önemli hedefi Abbasi hakimiyetinde bulunan Hicaz bölgesini ele geçirmek olmuştur. Çünkü Fatımîler açısından buralara hakim olmak hem siyasi hem de dini nüfuzlarının artması anlamına gelmekteydi. Ayrıca İslam dünyasında Hicaz bölgesinin siyasi egemenliğini elinde bulunduranlara Emirü’l-Mü’minîn ünvanı verilmekteydi. İslam dünyasının liderliği ile ilgili bir simge haline gelen bu unvan halifeden halifeye devralınır, Mekke ve Medine'de bu halifelere dua edilirdi. Dolayısıyla bu durum da Abbasî ve Fatımî hilafetinin Hicaz'da varlığını ve nüfuzunu sürdürmesi için çatışmalara neden olmuştur. ${ }^{35}$

\footnotetext{
${ }^{28}$ Ahmad b. Muhammad İbn-Halkan, Vefiyet el-Ayan ve Enba' Ebna'El-zaman, C.1, Dar Sadir Yayınları, Beyrut 1972, s.376; Çelik, age, s.207-208.

${ }^{29}$ Yazılitaş, age, s.50.

${ }^{30}$ Tekiyyu'l-din Ahmad b. Ali El-Mikrizî, El-Mevaiz ve El-ittibar Bizikir El-Hutat ve Esar, C.1, Daru'l-Sadık, Beyrut, 1988, s.177.

${ }^{31}$ Çelik, age, s.186-187.

32 Komutan Cefar b. Felah'ın gerçekleştirdiği bu zaferlere rağmen bazı şehirlerin ahalisi özellikle Dımaşk'taki ahali Fatımîlerin buradaki siyasi istikrarını sarsmak için faaliyette bulundular. Bunun sebebi ise insanlara karşı izlenen hiddet ve şiddet politikasıdır. Bu politikalar tarafların arasında uzlaşma durumu yaratmaya imkan sağlamamıştır. Bu nedenle komutan Cafer, Fatımîlerin mezhebi ve fikri yayılmasında sıkıntılar yaşayarak başarısız olmuştur. Bkz. Muhammad Cemal-edin Surûr, Siyaset el-Fatimiyyin el-Hariciyye, Daru'l-Fikir el-Arabi Yayınları, Kahire 1967, s. 120 .

${ }^{33}$ Muhammad Cemaleddin Surûr, El-Nufuz el-Fatimî Fi Bilad El-Şam ve El-Irak, Kahire 1959, s.16-17; Çelik, age, s.188-189.

${ }^{34}$ Çelik, age s.191-192.

35 Aburrahman b. Muhammad İbn-Haldûn, El-Mukadime, Dar-Ya'rub Yayınları, Şam 2004, s. 228.
} 
Fatımîlerin Hicaz'daki ilk nüfuzu 968 yılında Mekke emiri Cafer b. Muhammad El-Hüsnî’nin Mekke'de Halife El-Muiz adına hutbe okutmasından sonra Fatımîlere bağlı olduğunu göstermesiyle açık bir şekilde ortaya çıkmıştır. ${ }^{36}$ Bunun üzerine El-Muiz bu siyasi zaferi takviye etmek amacıyla Şam'1 egemenliği altına alarak Mekke ve Kahire'yi bağlayan kara yolunun güvenliğini sağlamıştır. ${ }^{37}$ Abbasîler ise bu duruma karşı Karmatîler ${ }^{38}$ aracılığıyla 969 yılında yeniden Hutbeyi Halife Mutî (945-974) ve onun müttefiği Hasan el-Asam el-Hurmütî adına okutmayı başarmışlardır. Fatımîler, Karmatîlerin bu müdahalesine karşı Medine'nin Hüseynî hakimlerini Mekke'yi zorla ele geçirmek için destekleyip hutbeyi Halife Muiz adına tekrar okutmuşlardır. Ancak bu başarı uzun sürmemiştir zira Karmatîler Mekke'nin ahalisine katılarak, Mekke'de üstünlük sağlayıp 970 yılında Hüseynîleri, Medine'ye göç etmek zorunda bırakmışlardır. ${ }^{39}$ Hicaz'da durum bu şekilde bazen Fatımî nüfuzunun bazen de Abbasî nüfuzunun egemen olması şeklinde devam etmiştir. Diğer yandan Fatımîler Hicaz'da nüfuzlarını arttırmak için Kurban bayramlarında Kâbe'ye örtü göndermişlerdir. Bu şekilde dayranarak bölge halk1 üzerinde hem manevi hem de siyasi iz bırakmayı amaçlamışlardır. Ayrıca Hac yolunun güvenliğini sağlamak için zaman zaman askerler de görevlendirmişlerdir. ${ }^{40}$

Yemen'de ise Şî̂ dailerinin propagandaları etkili olmuş birçok kişi İsmâiliyye mezhebine tabi olmuştur. Bu durum Fatımîlerin Yemen'deki durumunu kuvvetlendirmiştir. Hatta zamanla Yemen, Fatımîlerin siyasi üssü haline gelmiştir. Buradan Hindistan ve Kuzey Afrika'ya Fatımî davetçileri gönderilmiştir. Yemen ile yapılan bu güçlü bağlantılar ve siyasi ilişkiler Fatımîlerin Mısır'daki varlığını stratejik açıdan daha da güçlendirmiştir. ${ }^{41}$

\section{Mısır'ın Ele Geçirilmesinden Sonra Fatımı-Doğu Roma İlişkileri}

Fatımîlerin İhşîlî hakimiyetine son vererek Misır, Suriye ve Hicaz ${ }^{42}$ bölgesinde hakimiyet

Volume 12

Issue 5

October

2020 kurması Batı Akdeniz'den sonra bu kez de Doğu Roma'nın Doğu Akdeniz'deki varlığını tehdit etmeye başlamıştır. ${ }^{43}$ Dolayısıyla hem Fatımîler hem de Doğu Roma İmparatorluğu Akdeniz'de hakim olabilmek ve kıyı bölgelerindeki şehirleri ele geçirmek için birbirleri ile mücadele etmişlerdir. Fatımîlerin Mısır'ı ele geçirdikten sonra Suriye bölgesine hakim olmaları Suriye'nin Doğu Roma'ya sınır olması nedeniyle Doğu Roma için büyük bir tehdit oluşturmuştur. ${ }^{44}$ Diğer yandan islam dünyası içerisinde çıan siyasi karışıklıklar, şiî-sunni çatışması ve Abbasi Devleti'nin siyasi otoritesinin zayıflaması Doğu Roma İmparatorluğu için büyük bir firsat olarak değerlendirilmiştir. ${ }^{45}$ Doğu Roma İmparatorluğu içerisinde ise iç savaşların bitmesi, merkezi iktidarın güçlenmesi de doğu sınırlarında yayılmacı bir politika gerçekleştirmek için harekete geçmesine neden olmuştur. ${ }^{46}$

\footnotetext{
36 Muhammad b. Ahmad El-Fasî, Şifâ'ül-garâm bi-ahbâri'l-beledi'l-harâm, C.2, Daru'l-Kutup el-İlmiyye Yayınları,Beyrut 1985, s.194.

${ }^{37}$ Ahmad El-Zeilî, Mekke ve Alakatiha el-Hariciyye( H.301-487), El-Daru'l Arabiyye Yayınları, Riyad,2004,s.42.

${ }^{38}$ El-Cevarî, age, s.86.

${ }^{39}$ El-Cevarî, age,s.87.

${ }^{40}$ El-Cevarî, age,s.89-91.

${ }^{41}$ Vahyidin Ali el-Şibanî İbnu'l-Dîba, Kurra el-Uyûn fi Ahbar El-Meymûn, Elekva Yayınları, Kahire,1977,s.144; Hasan Mahmud El- Cuhaynî, El-Salihiyyûn ve El-Hareka el-Fatimîyye fi Yemen, Matbaa el-Risale Yayınları, Kahire, 1955, s.27-28

42 Fatımîlerin Hicaz'da Abbasilere karșı izlediği politikalar hakkında daha geniş bilgi için bkz. Aydın Çelik, "Fatımîlerin Hicaz Politikası", Fırat Üniversitesi Orta Doğu Araştırmaları Dergisi, C.VI, S.2, Elazığ, 2010, s.145162; İbnü'l Esir, age,s.508-509.

${ }^{43}$ Bernard Lewis, Fatımîler ve Hindistan Yolu, İsmail Akgün Matbaas1 Yayınları, İstanbul 1952,s.356-357;Öztürk, age, s.109;Çapan, agm, s.277.

${ }^{44}$ Öztürk, agt, s.113.

45 Abdulmine'm Macid, El-Hâkim Bi-Amr'illah, İnclumasriyye Mektebe Yayınları, Kahire, 1982, s. 129.

${ }^{46}$ El-Cevarî, age,s.133.
} 
969 yılında Dımaşk üzerine doğru yola çıkan Doğu Roma ordusu Humus şehrine girerek şehrin gençleri ve çocuklarını esir almıştır. ${ }^{47}$ Doğu Roma'dan gelen bu tehditlere karşı Fatımîler ise İskenderiye ve Dimyat'ta bulunan tersanelerde büyük bir askeri filo inşa etmeye başlamıştır. Hazırlanan askeri filolar Akkâ, Askalan ve Sur gibi limanlara gönderilmiştir. Böylece Akdeniz'in doğu kısmı bir Fatımî gölü gibi olmuştur. ${ }^{48}$ Fatımîler, 971 yılında Antakya'ya saldırınca Doğu Roma İmparatoru I. Ioannes Çimiskes(969-976) Suriye üzerine büyük bir sefere çıkmıştır. 972 yılında öncelikle Meyyafarikin'e taarruz eden imparatorun asıl savaşı Suriye sahasında cereyan etmiştir. Antakya'dan Baalbek'e yürüyen imparator daha sonra Dımaşk'1 ele geçirmiştir. Çimiskes bundan sonra Filistin içlerine ilerleyerek sahil şehri Akkâ ve Fatımîlerin ana üssü olan Kaysâriye'yi ele geçirmiştir. Daha sonra kuzeye doğru ilerleyerek Beyrut gibi önemli kıyı şehirlerini zaptetmiştir. İmparator bundan sonra müttefiki Ermeni Kralı III. Aşot'a gönderdiği bir zafernamede "bütün Finike, Filistin ve Suriye Arapların boyunduruğundan kurtarılmış olup Romalıların hakimiyetlerini kabul etmiştir" demiştir. Ostrogorsky’e göre bu ifadeler mübalağadan ibaret olup imparatorun yaptıklarını değil yapmak istediklerini göstermektedir. Çimiskes bu seferin dönüșünde muhtemelen tifüs hastalığına yakalanarak 10 Ocak 976 tarihinde İstanbul'da ölmüştür. ${ }^{49}$ Ancak Çimiskes'in ölümünden sonra Halife AzîzBillâh(975-996) döneminde Fatımîler 978 yılına kadar Antakya ve Halep'e kadar tüm Suriye bölgesini yeniden ele geçirmiştir. ${ }^{50}$

Çimiskes'in ölümünden sonra Doğu Roma İmparatorluğu'nda bir süre taht karışıklıkları yaşanmıştır. Bunu firsat bilen Fatımî Halifesi Azîz-Billâh Doğu Roma'ya saldırmak için hazırlıklara başlamıştır. Bunu duyan ve tahta yeni çıkan İmparator II. Basileios(976-1025) Kahire'ye elçiler göndererek Fatımîler ile barış yapmak istemiştir. Çünkü o dönemde Doğu Roma bir yandan Makedonya'da çıkan bir isyanı bastırmakla meşgul olurken diğer yandan da Bulgarlar ile savaşmak uğraşmak zorunda kalmıştır. ${ }^{51}$ Bunun üzerine 987-988 yıllarında 7 yı1 süreli bir anlaşma yapılmıştır. Anlaşmaya göre Doğu Roma'nın elinde bulunan Müslüman esirler serbest bırakılacak, İstanbul'daki camide hutbeler Fatımîler adına okunacak ve Fatımîlerin istediği malların tedarik edilmesinde kolaylık sağlanacakt $1 .{ }^{52}$

Doğu Roma İmparatoru bundan sonra Bulgarlar üzerine sefere çıkmıştır. Fatımîler ise 991 yılında Halep'i kuşatmıştır. Bunun üzerine Halep emiri Ebe'l-Fâdil b. Hamdan(967-991), Bizans imparatoru II. Basileios'tan yardım istemiştir. Bu yardım talebine olumlu cevap veren Doğu Roma İmparatoru Halep emirine bir ordu göndermiştir. İki ordu arasında Asi nehri civarında yapılan savaşta Doğu Roma ordusu yenilgiye uğramıştır. Fatımî ordusu kumandanı Mencutekin ise savaş bittikten sonra erzak tedarik etmek için Şam'a gitmiştir. Daha sonra tekrar ordusu ile birlikte Halep'e dönerek şehri kuşatmıştır. Fatımîler bir yandan Halep kuşatmasına devam ederken bir yandan da Asi nehrinin etrafinda Doğu Roma birliklerine karşı zaferler elde etmeye devam etmişlerdir. Fatımîlerin Halep kuşatması sırasında yiyecek ve erzak bakımından zor duruma düşen Halep Valisi Lü'lü' el-Hadim, Halep'in Fatımîlerin eline düşmesinden çekinerek Doğu Roma İmparatoru II.Basileios'a bir mektup göndermiştir. Mektubunda imparatora hitaben "Ne zaman Halep düşerse Antakya düşer, ne zaman Antakya düşerse Konstantinopolis düşer" "53 demiştir. Bunun üzerine imparator II.Basileios 995 yılında bizzat Halep surları önlerine

\footnotetext{
47 İbnü'l Esir, age ,C.VII, s.34.

${ }^{48}$ Mahir Suad, El-Bahriyye el-İslamiyye ve Esariha el-Bakiye, Daru'l-Kitap el-Arabi Yayınları, Kahirev1967,s.97.

${ }^{49}$ Ostrogorsky George, Bizans Devleti Tarihi, Çev:Fikret Işıltan, TTK Yayınları, Ankara 1999, 275-276;Çelik, age, s.218-219; El-Cevarî, age,s.140-143.

${ }^{50}$ Levtchenko, age, s.235-236.

${ }^{51}$ Ostrogorsky, age,279-280; Levtchenko, age,s.237-238; Yazılıtaş, age, s.63.

${ }^{52}$ Muhammad b. Ahmad Dahabî, Tarih el-İslam, Daru'l Kutub El-Arabi Yayınları, Kahire, 1990,s.481.

${ }^{53}$ Ali b. Muhammad İbn-Kalanisî, Tarih-i Dımaşk, Daru'l-İhsan Yayınları, Kahire, 1983, s. 41.
} 
gelmiştir. İmparatorun bu hamlesi Fatımîler tarafından beklenmediği için bu durum onların hazırlıksız yakalanmalarına neden olmuştur. Nitekim Doğu Roma orduları Raphanea(Rafanîya) ve Emesa(Hıms) gibi yerleri işgal ettikten sonra Trablusşam'a yönelmiştir. Ancak İmparator burayı ele geçiremeyince İstanbul'a geri dönmüştür. ${ }^{54} 996$ yılında Fatımî Halifesi Aziz, Doğu Roma ordularını püskürtmek amacıyla ordusunun başında Şam'a doğru yola çıkmış ancak yolda hastalanarak vefat etmiştir. ${ }^{55}$

Fatımî Halifesi Hâkim-Biemrillâh (996-1021), Doğu Romalılarla yapılan 7 yıllık sureli anlaşma süresinin bitiminden sonra onların anlaşmazlıkların odak noktası olan Suriye'ye müdahale etmesinden çekinmeye başlamıştır. Bu nedenle Doğu Romalıların güneye inmelerini engellemek için iki sefer düzenlemiştir. Bu savaşların birincisinde Taberiyye yakınlarında yapılan deniz savaşında, ikincisinde Famiya(Ephameya) yakınlarında yapılan kara savaşında Doğu Roma orduları yenilgiye uğratılmıştır. Bu yenilgiyi öğrenen imparator elçileri aracıllğıyla barış istemiştir. Bu elçilik heyeti Fatımîler tarafından ihtişamlı bir törenle karşılanmış ve bu kez 10 y1l savaşmamak şartı içeren bir anlaşma yapılmıştır. Ancak bu anlaşmaya rağmen Doğu Roma İmparatorluğu zaman zaman Fatımîlerin düşmanlarıyla işbirliği yapıp Suriye bölgesine saldırmışlardır. ${ }^{56}$ Nitekim Doğu Roma İmparatorluğu Fatımîlerin Suriye'deki nüfuzunu kırmak amaciyla yeniden harekete geçtiyse de 999-1000 y1llarında meydana gelen savaşlarda yenilgi alarak geri çekilmek zorunda kalmıştır. ${ }^{57}$ Fatımîler bu başarılarına rağmen Mısır'da çıkan iç karışıklıklara son vermek amacıyla 1002 yılında Doğu Roma İmparatorluğu ile barış yapmak için bir elçilik heyeti göndermiştir. Bundan memnuniyet duyan İmparator II. Basileios teklifi kabul etmiştir. Anlaşmaya göre Fatımî sınırlarında yaşayan Hıristiyanlara özgürlük tanınacak, onlara kiliselerini inşa etme ve onarma imkanı verilecek, buna karşılık Doğu Roma ise Mısır'ın ihtiyacı olan hubabatı gönderecek ve yine anlaşma on yıl boyunca geçerli olacakt1. ${ }^{58}$ Ancak yine de her iki taraf arasında Suriye bölgesindeki hakimiyet mücadelesi devam etmiştir. HâkimBiemrillâh'tan sonra yerine geçen oğlu Zâhir-Lii'zâziddînillâh(1021-1036) döneminde Doğu Roma İmparatoru II. Basileios Bulgarlar ve Ruslardan oluşan büyük bir orduyu Güney İtalya'ya göndermiştir. Bu ordu kısa zamanda Calabria'ya ulaşarak yönetime hakim olmuş ve Sicilya'yı tehdit etmeye başlamıştır. II. Basileios'un ölümü ve yerine oğlu VIII.Konstantinos'un(10251028) geçtiği dönemde Sicilya Doğu Roma İmparatorluğu tehdidinden kurtulmuştur. Bu sırada 1027 yılında Doğu Roma ile Fatımîler arasında bir barış anlaşması yapılmıştır. Buna gore:

* İstanbul'daki cami ibadete açılacak,

* Hutbe Fatımîler adına okunacak,

* Buna karşıllk ise Kudüs’teki Kıyâme kilisesi tekrar açılacak bundan sonra Doğu Roma’ya karşı Fatımîler Sicilya valisine yardım etmeyeceklerdi. ${ }^{59}$

Nitekim Zâhir-Lii'zâziddînillâh'dan sonra yerine geçen oğlu Mustansır-Billâh(1036-1094) döneminde de Doğu Roma ile Fatımîler arasında yeni bir anlaşma yapılmıştır. Bu anlaşmada da diğer anlaşma şartlarına ek olarak Fatımîler'in Mısır'da bulunan 50.000 Hıristiyan esiri serbest

\footnotetext{
${ }^{54}$ Yusuf b. Tiğrî Burdî, El-Nucum el-Zahire fi Muluk Misır ve El-Kahire, C.4, Mısır Kültür Bakanlığı Yayınlar1, Kahire, 1963, s. 121.

${ }_{55}^{55}$ Burdî, age, s. 122.

56 Marina Atila, XI.-XII.Yüzyıllar (1055-1171) Selçuklu-Fatımî İlişkileri, (Yayınlanmamış Doktora Tezi), Ankara,1996, s.33-34;Ali İbrahim Hasan, Misır fi El-Usuru'l-vusta min El-fathi'l-Arabî ile El-fathi'l-Osmanî, Mektebatü'l-nahda Yayınları, Kahire 1947, s. 231.

57 Çelik, age, s.280-281; Öztürk, agt, s.119-120.

${ }^{58}$ Çelik, age, s.281.

59 Öztürk, agt, s.121-122;Çelik, age, s.298; El-Cevarî, age, s.150.; Hasan, age s. 231.
} 
bırakmasına karar verilmiştir. ${ }^{60}$ Doğu Roma ile Fatımîler arasında yapılan bu anlaşma 1047 veya 1048 yılında yenilenerek her iki taraf da birbirlerine kıymetli hediyeler göndermiştir. Mikha1l Psellos bu durumu şu şekilde ifade etmektedir: “...Imparator sadece sınırlarımız içindeki şehirlerde iyi idare sağlamakla kalmadı, hudutlarımızın ötesindeki milletlerin Roma topraklarına saldırmalarını da önledi. Bunu kısmen elçi göndererek, kısmen haraç vererek, kısmen de her yıl askerî gücünü göstererek yaptı. Bu tedbirler sayesinde ne Misır, ne İran ne de Irak hükümdarları bizimle yapmış oldukları anlaşmalara karşı çıktılar...". ${ }^{61}$ Nitekim Doğu Roma İmparatorluğu Sicilya'da Araplar ile savaşmak üzere 1036 tarihinde Georgios Maniakes'i görevlendirmiştir. ${ }^{62}$ İki yıl süren hazırlıklardan sonra burada büyük başarılar elde edilmiş ve 1038 yılında Sicilya'nın doğu kısmı ele geçirilmiştir ${ }^{63}$ ve Fatımîler söz verdikleri gibi Sicilya'ya yardım etmemişlerdir. Bu durum ise Fatımîlerin yavaş yavaş Kuzey Afrika ve Sicilya'dan uzaklaşmaya başladıklarının önemli bir göstergesidir. ${ }^{64} \mathrm{Bu}$ arada VIII. Konstantinos'un ölümünden sonra Doğu Roma İmparatorluğu tahtında yaşanan siyasi karışıklıklar nedeniyle sık sık İmparator değişikliği olmuştur. Nitekim bahsi geçen süreçte Fatımîler ile Doğu Romalılar arasında herhangi bir sorun yaşanmamıştır. Hatta Doğu Roma, Selçuklulara karşı Fatımîlerle işbirliği dahi düşünmüştür. Bu durum Doğu Roma İmparatorluğu'nun Selçukluları Fatımîlerden daha tehlikeli bir düşman olarak gördügünü ispatlamaktadır. Bu nedenle IX.Konstantinos(1042-1055) tahta çıktığında Selçuklulara karşı ittifak yapma düşüncesiyle Fatımîler ile yapılan anlaşmayı yenilemiştir. Karş1lıklı olarak gönderilen elçilik heyetleri ile birlikte her iki taraf da birbirine değerli hediyeler göndermiştir. 1054 yılında Mısır'da yaşanan kıtlık nedeniyle Fatımî Halifesi Mustansır-Billâh, Kadı Ebû El-Kudâ'i aracılı̆̆ıyla gönderdiği mektupla imparatordan buğday talep etmiştir. Ancak imparator bu talebi karşılamaya hazırlanırken vefat etmiştir. Yerine geçen İmparatoriçe Theodora(1055-1056) ise bu destek karşıllı̆ında Selçuklular aleyhine bir ortak savunma anlaşmasını şart koşmuştur. Ancak Mustansır-Billâh bu anlaşmayı kabul etmeyince Doğu Roma bu yardımı göndermediği gibi bu kez Selçuklular ile Fatımîler aleyhine anlaşma yolları aramaya başlamıştır. $^{65}$

1055-1056 y1lında Tuğrul Bey'in girişimi ile İstanbul'daki camide hutbenin Abbasi Halifesi adına okunmaya başlamasıyla Doğu Roma-Fatımî ilişkileri gerginleşmeye başlamıştır. Mustansır-Billâh, Kıyâme kilisesi ile birlikte Suriye ve Mısır'daki diğer kiliseleri kapatarak Hıristiyanlardan aldığı vergiyi arttırmıştır. Ayrıca Lazkiye'ye hücum eden Fatımî ordusu burayı ele geçirmiş ve daha sonra Antakya topraklarına girerek Efamiye'ye yakın Kastûn kalesini Doğu Roma'dan geri almıştır. Bunun üzerine harekete geçen Theodora 80 parçalık bir donanma göndermiş ve 1056 yılında hem karadan hem de denizden Trablus muhasara edilmiştir. Burada meydana gelen savaşta Doğu Roma ordusu yenilerek kuzeye doğru geri çekilmiştir. Ancak bu sırada Antartus'a girerek çok sayıda Müslümanı öldürmüşler ve birçok esir almışlardır. Ardından Lazkiye'ye dönüp şehri istila etmişlerdir. Bunun üzerine Mustansır-Billâh, Theodara'ya elçi göndererek barış istemek zorunda kalmıştır. Bu sırada Selçuklu Sultanı Tuğrul Bey'in mektubunu getiren elçinin de orada olması nedeniyle Fatımî elçisine gereken ilgi

\footnotetext{
${ }^{60}$ Işın Demirkent, Mıkhaıl Psellos'un Khronographıa 'sı, TTK Yayınları, Ankara, 2014, s.61.

${ }^{61}$ Demirkent, age, s.178.

${ }^{62}$ Demirkent, age, s.133.

${ }^{63}$ Ostrogorsky Doğu Roma'nın bu seferlerini şu şekilde ifade etmektedir: “Georgios Maniakes'in Sicilya'daki askeri harekâtı, her tarafında kararmaya başlamış olan Bizans ufkunda çıkan son ve kısa bir ışık huzmesi idi. Sanki II. Basileios'un yerine getirmek üzere, zaferlerle dolu Makedonya hanedanının fütühat devresinin geç bir temsilcisi olan Georgios Maniakes, Messina ve Syrakusa dahil olmak üzere Sicilya'nın doğu kısmını Müslümanlardan koparıp aldı. Georgios Maniakes'in gerek doğuda gerekse Sicilya'da giriştiği başarılı teşebbüsler Bizans Devleti'nin Araplara karş1 üstünlüğünü teyid etmişti...” Bkz. Ostrogorsky, age, s.308-309.

${ }^{64}$ Öztürk, agt, s.123.

${ }^{65}$ Çelik, age, s.340-341.
} 
gösterilmemiştir. Çünkü artık Doğu Roma, Fatımîlere karşı daha güçlü olan Selçuklularla anlaşmak istemektedir. Böylece Selçuklular ile siyasi münasebetlerini düzenlemeye çalışan Doğu Roma İmparatorluğu'nun Fatımîlerle olan ilişkileri kopma noktasına gelmiştir. ${ }^{66}$ Mikha1 Psellos'un Khronographıası'nda bu durum şu şekilde anlatılmıştır: “...Mısır hükümdarı da Isaakios'tan korkuyor ve ona güzel sözler söyleyerek iyi geçinmeye çalışıyordu. Hatta Isaakios'un düşmesinden dolayı matem tutmak gibi aşırıya kaçan bir harekette bulundu....". ${ }^{67}$

Selçukluların etkin bir şekilde siyasi hayata girmesi ve Suriye'ye hakim olma çabaları ile birlikte XI. Yüzyılın sonlarında başlayan Haçlı seferleri nedeniyle Fatımîler yavaş yavaş zayıflamaya başlamıştır. ${ }^{68}$ Nitekim 1061-1091 yılları arasında Sicilya'nın Normanlar tarafından işgal edilmesi de Fatımîler aleyhine bir gelişme olmuştur ve gemi yapımı için sağlanan birçok malzeme artık temin edilemez olmuştur. ${ }^{69}$ Diğer yandan Mustansır-Billâh'ın ölümünden sonra oğlu Musta'lî-Billâh'ın(1094-1101) kardeşi ile yaptığı mücadele devletin zayıflamasında oldukça etkili olmuştur. Ayrıca XI. asrın sonlarına doğru Normanlar, Venedikliler, Cenevizliler, Franklar gibi Batı Avrupalıların, Batı Akdeniz' in büyük bir kısmına hakim olmaları da hem Doğu Roma'nın hem de Fatımîlerin hakimiyetini sarsmıştır. ${ }^{70}$ Haçlı seferlerinin başlamasıyla Doğu Roma ile Fatımîler arasındaki çatışma dönemi sona ermiştir. ${ }^{71}$ Diğer yandan Haçlı seferleri sırasında Müslümanların elindeki şehirler birer birer elden çıkarken Fatımîler ve Abbasiler arasındaki iktidar kavgası nedeniyle Mısır'a dışarıdan müdahaleler oldukça kolaylaşmışıtır. ${ }^{72}$ XII. Yüzyılın sonlarına doğru Mısır artık Haçlıların rahatlıkla girip çıktığı bir yer halini alırken Haçlı tehlikesine karşı savaşan Nûreddin Mahmûd Zengi'nin gerçekleştirdiği seferler sonunda iki buçuk asırlık Fatımî Devleti'ne son verilmiştir. ${ }^{73}$

\section{Sonuç}

Tunus merkezli olarak kurulan Fatımî Devleti'nin asıl hedefi Mısır'ı ele geçirmek olmuştur. Çünkü Mısır Jeopolitik konumu açısından Fatımîler için ayrıca bir önem arz etmiştir. Doğu'da Abbasilere karşı başarılı bir mücadele vermek ve İslam dünyasının en güçlü devleti olabilmek için buna ihtiyaç duyulmuştur. Ancak Fatımî Devleti kurulduğu ilk yarım asır içerisinde sürekli olarak Batı Akdeniz'de Güney İtalya ve Sicilya bölgelerinde Doğu Roma İmparatorluğu ve Endülüs Emevi Devleti'ne karşı yoğun mücadeleler vermek zorunda kalmıştır. Bu nedenle doğudaki amaçlarına yönelik askeri harekâtlar sınırlı kalmıştır. Zaman zaman Mısır'a seferler düzenlense de Abbasilerin burada bulunan İhşıdîleri desteklemesi nedeniyle başarıya ulaşılamamıştır. Nihayetinde Batı Akdeniz'de kurdukları donanma sayesinde önemli bir otorite haline gelen Fatımîler Mısır'a güçlü bir şekilde yönelme imkanı bulmuş ve 969 yılında Mısır ele geçirilerek devlet merkezi haline getirilmiştir. Mısır'ın ele geçirilmesinden sonra siyasi gücünü pekiştirmek isteyen Fatımîler Suriye ve Hicaz bölgelerine yönelmiştir. Bunlardan Suriye stratejik açıdan Fatımîlerin egemen olmak istedikleri coğrafyalara açılan önemli bir kapı konumundayken Hicaz ise İslam dünyasının hakimiyetini ele geçirmek açısından manevi bir öneme sahiptir. Nitekim Fatımîlerin özellikle Suriye'ye yönelik hareketleri Doğu Roma İmparatorluğu'nu rahatsız etmiştir. Çünkü Suriye Doğu Roma'ya sınır olması nedeniyle büyük bir önem arz

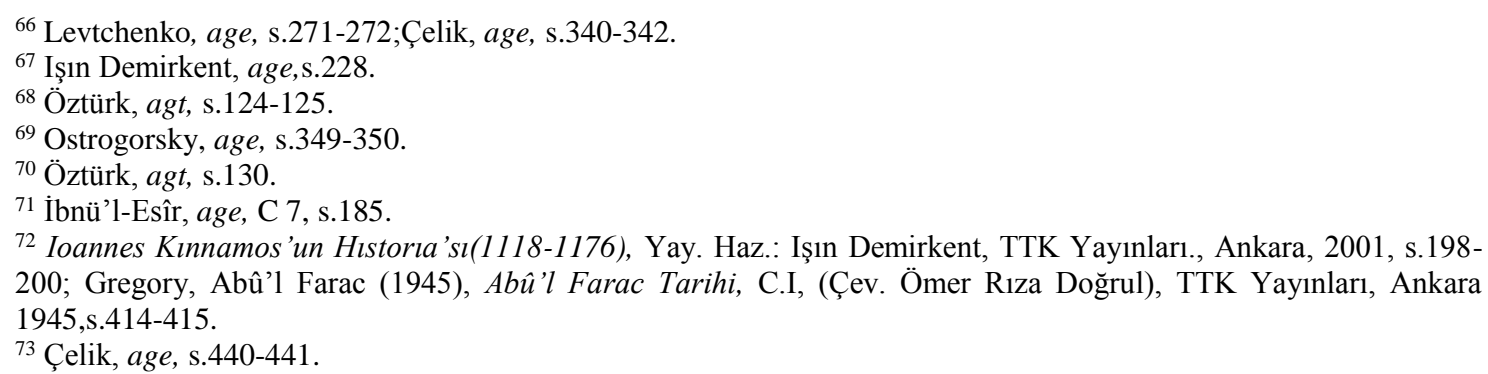


etmekteydi. Nitekim Doğu Roma İmparatorluğu, daha önceki tarihlerde de Suriye hakimiyeti için Sasaniler ve Araplara karşı önemli mücadeleler vermiştir. Bu bölgelerde cereyan eden Doğu Roma-Fatımî mücadelelerinde taraflar arasında zaman zaman şiddetli savaşlar meydana gelmiştir. Bu savaşlar sonunda süreli barış ve vergi ödeme gibi şartlar içeren anlaşmalar yapılsa da bu anlaşmalar kısa bir süre sonra ihlal edilerek yeniden savaş yoluna gidilmiştir. Bu savaşlar devam ederken doğuda Selçuklu Devleti'nin güçlü bir şekilde ortaya çıkması ve Abbasi Halifelerinin Selçuklularla ittifak yapması Doğu Roma İmparatorluğu için yeni ve daha kuvvetli bir düşmanın ortaya çıkmasına neden olmuştur. Hatta bu güçlü düşmana karşı artık daha tehlikesiz görülen Fatımîlerle işbirliği yapılmaya çalışılmıştır. Ancak bu girişimler başarısızlıkla sonuçlanmıştır. Diğer yandan XI. asrın sonlarında başlayan Haçlı Seferleri, Doğu Roma İmparatorluğu, Selçuklular ve diğer İslam devletleri için durumu çok daha karmaşı hale getirmiştir. Bu karmaşı ortam içerisinde başarılı politikalar üretemeyen Fatımîler İslam dünyasının en güçlü ve tek hükümdarlığı olma hayallerini gerçekleştiremeyerek yıkılmıştır. Doğu Roma İmparatorluğu ise asırlardır mücadele ederek bir şekilde elinde tutmayı başardığı doğu memleketlerini Selçukluların gelişiyle bir daha ele geçirememek üzere kaybetmişlerdir.

\section{Kaynakça}

ABÛ'L FARAC, Gregory, Abû'l Farac Tarihi, C.I, Çev: Ömer Rıza Doğrul, TTK Yayınları, Ankara 1945.

ATILA Marina, XI.-XII.Yüzyıllar (1055-1171) Selçuklu-Fatımî İlişkileri, (Yayınlanmamış Doktora Tezi), Ankara,1996. HASAN Ali İbrahim, Misir fi El-Usuru'l-vusta min Elfathi'l-Arabî ile El-fathi'l-Osmanî, Mektebatü'l-nahda Yayınları, Kahire 1947.

BURDÎ Yusuf b. Tiğrî, El-Nucum el-Zahire fi Muluk Misır ve El-Kahire, C.4, Misır Kültür Bakanlığı Yayınları, Kahire, 1963.

CEMALEDDİN Abdullah, Devletu'l-Fatimiye Kiyemuha fi El-Mağrib ve Intikaliha ile Mistr, Dar'ul-Sekafe Yayınları, Kahire, 1991.

ÇAPAN Fatma, "Batı Akdeniz'de Doğu Roma İmparatorluğu-Fatımî Siyasi İlişkileri”" Kahramanmaraş Sütçü İmam Üniversitesi Sosyal Bilimler Dergisi, C.17, S.11, Kahramanmaraş 2020, s.274-293.

ÇELIKK Aydın, "Fatımîlerin Hicaz Politikası", Fırat Üniversitesi Orta Doğu Araştırmaları Dergisi, C.VI, S.2, Elazığ, 2010, s.145-162.

ÇELIKK Aydın, Fâtımîler Devleti Tarihi(909-1171), TTK Yayınları., Ankara,2018.

DAHABÎ Muhammad b. Ahmad, Tarih el-İslam, Daru'1 Kutub El-Arabi Yayınları, Kahire, 1990.

DEMİRKENT Işın, Ioannes Kınnamos'un Hıstorıa'sı(1118-1176), Yay. Haz.: Işın Demirkent, TTK Yayınları., Ankara, 2001.

DEMİRKENT Işın, Mıkhaıl Psellos'un Khronographıa'sı, TTK Yayınları, Ankara, 2014.

EL-CEVARİ Riyad, El-Siyase el-Hariciyye Lil-Devletu'l-Fatimiyye M.968-1035, Kufa Üniversitesi Yayınları, Kufa, 2007.

EL-CUHAYNî Hasan Mahmud, El-Salihiyyûn ve El-Hareka el-Fatimîyye fi Yemen, Matbaa elRisale Yayınları, Kahire, 1955.

EL-FASÎ Muhammad b. Ahmad, Şifầ'ül-garâm bi-ahbâri'l-beledi'l-harâm, C.2, Daru'l-Kutup el-İlmiyye Yayınları,Beyrut 1985. 
EL-MIKRİZî Tekiyyu'l-din Ahmad b. Ali, El-Mevaiz ve El-İtibar Bizikir El-Hutat ve Esar, C.1, Daru'l-Sad1k, Beyrut 1988.

EL-ZEİLI Ahmad, Mekke ve Alakatiha el-Hariciyye( H.301-487), El-Daru'l Arabiyye Yayınları, Riyad,2004.

GEORGE Ostrogorsky, Bizans Devleti Tarihi, Çev:Fikret Işı1tan, TTK Yayınları, Ankara 1999.

İBNU'L DÎBA Vahyidin Ali el-Şibanî, Kurra el-Uyûn fi Ahbar El-Meymûn, Elekva Yayınları, Kahire,1977.

İBN-HALDÛN Aburrahman b. Muhammad, El-Mukadime, Dar-Ya'rub Yayınları, Şam 2004.

İBN HALKAN Ahmad b. Muhammad, Vefiyet el-Ayan ve Enba' Ebna'El-zaman, C.1, Dar Sadir Yayınları, Beyrut 1972.

İBRAHIM Hasan, Tarih El-devletu'l-Fatimiyye, Mısır Lìl-tiba'a ve El-Neşir Yayınları, Kahire, 1958.

İBN-KALANíSî Ali b. Muhammad, Tarih-i Dımaşk, Daru'l-İhsan Yayınları, Kahire, 1983.

LEVTCHENKO Metrofan Vasiliyeviç, Bizans, Çev: Erdoğan Berktay, Milliyet Yayınları, İstanbul 1979.

LEWIS Bernard, Fatımîler ve Hindistan Yolu, İsmail Akgün Matbaası Yayınları, İstanbul 1952.

LEWIS Bernard , Uygarlık Tarihinde Araplar, Pegasus Yayınları., İstanbul, 2006.

MACID Abdulmine'm, El-Hâkim Bi-Amr'illah, İnclumasriyye Mektebe Yayınları, Kahire, 1982.

MADENÎ Ahmad Tevfik, El-Muslimin fi Cezire Siklliyye ve Cenup İtalya, Mektaba İstikame Yayınları, Tunus, 1981.

ÖZTÜRK Murat, Fâtımiler'in Deniz Gücü ve Akdeniz Hâkimiyeti, İstanbul Üniversitesi Sosyal Bilimler Enstitüsü (Yayınlanmamış Doktora Tezi), İstanbul 2012.

SEID Ayman Fu'at, El-Devletu'l-Fatimiye Tefsir Cedid, Mekteba El-Usra Yayınları, 2007.

SUAD Mahir, El-Bahriyye el-İslamiyye ve Esariha el-Bakiye, Daru'l-Kitap el-Arabi Yayınları, Kahire 1967.

SURÛR Muhammad Cemaleddin, El-Nufuz el-Fatimî Fi Bilad El-Şam ve El-Irak, Kahire 1959.

SURÛR Muhammad Cemal-edin, Siyaset el-Fatimiyyin el-Hariciyye, Daru'l-Fikir el-Arabi Yayınları, Kahire 1967.

TOKUŞ Ömer, "Fâtımîler ile Sicilya ve Güney İtalya Arasındaki Münasebetler", Tarih Dergisi, S.59,İstanbul 2014, s.27-55.

YAZILITAŞ Nihat, Fâtımî Devleti'nde Türkler, TTK Yayınları, Ankara 2009.

İbnü'1 Esir, El Kâmil Fi’t Tarih, C.VIII., Çev:Ahmet Ağırakça, Bahar Yayınları, İstanbul 1986. 